\title{
ANALISIS POTENSI DAN STRATEGI PENGEMBANGAN OBJEK WISATA PANTAI PASIR KENCANA KOTA PEKALONGAN
}

\author{
Choliq Sabana, Suryani, Benny Diah Madusari, Suryo Pratikwo, Loso \\ Hartati, Ida Baroroh, Imam Suraji, Danang Satrio \\ Dewan Riset Daerah Kota Pekalongan
}

\begin{abstract}
This study entitled Potential Analysis and Development Strategy of Pasir Kencana Beach Tourism Object in Pekalongan City. The research objective to be achieved is to know and analyze the actual (physical and non-physical) aspects of tourism development in Pekalongan City beach attractions and analyze the development policy of coastal tourism objects in Pekalongan City as a strategy for planning Pekalongan City coastal tourism development and determining tourism development planning strategies sustainable tourism from coastal tourism objects in Pekalongan City in the context of developing coastal tourism. This research is descriptive, carried out to get a description or description of the assessment of aspects of the development of nautical tourism carried out through statistical calculations, then carried out an analysis of the development of attractions carried out using SWOT analysis techniques. Based on the objectives and results of the research conducted, conclusions can be drawn as follows: Overall, it can be concluded that the condition of the infrastructure and facilities of tourism at the Pasir Kencana Beach tourism location are still inadequate such as electricity networks and lighting, clean water networks, health facilities, facilities sanitation and hygiene, parking facilities, worship facilities, accommodation facilities, directions, which are still inadequate, and telecommunications networks, security facilities, financial facilities, business facilities, recreational facilities, information facilities and tourism services, tourism police and tourism units, souvenir shops, tourism information boards / tourist traffic signs, and landscape forms that are not yet available at the Pasir Kencana Beach tourism location.
\end{abstract}

Keywords : Development strategy, Tourism

\section{PENDAHULUAN}

Sektor pariwisata mempunyai peran yang strategis dalam perkembangan perekonomian di Indonesia di luar minyak bumi dan gas. Selain sebagai sumber penghasil devisa, sektor pariwisata mempunyai peranan yang besar dalam memacu dan menggerakkan sektor-sektor ekonomi lainnya, serta membuka berbagai lapangan kerja yang memungkinkan kesempatan kerja dan kesempatan berusaha lebih luas dan lebih merata.

Strategi pengembangan pariwisata pada prinsipnya berkaitan dengan persoalan: kebijakan pelaksanaan, penentuan tujuan yang hendak dicapai, dan penentuan cara-cara atau metode penggunaan sarana-prasarana. Strategi selalu berkaitan dengan 3 hal yaitu tujuan, sarana, dan cara. Oleh karena itu, strategi juga harus didukung oleh kemampuan untuk mengantisipasi kesempatan yang ada. Dalam melaksanakan fungsi dan peranannya dalam pengembangan pariwisata daerah, pemerintah daerah harus melakukan berbagai upaya dalam pengembangan sarana dan prasarana pariwisata.

Dalam perekonomian Indonesia sektor pariwisata terbukti telah memberikan kontribusi yang cukup besar pada perolehan devisa. Meningkatnya destinasi dan investasi pariwisata, menjadikan pariwisata sebagai faktor kunci dalam pendapatan ekspor, penciptaan lapangan kerja, pengembangan usaha dan infrastruktur. Pariwisata telah mengalami ekspansi dan diversifikasi berkelanjutan, dan menjadi salah satu sektor ekonomi yang terbesar dan tercepat pertumbuhannya di dunia; Kota dan Kabupaten di seluruh wilayah Indonesia saat ini banyak yang sedang berbenah diri dalam rangka 
memperkenalkan daerah mereka masing-masing melalui pengembangan destinasi wisata yang ada. Pengembangan destinasi wisata tidak saja bermakna memperkenalkan daerah mereka, lebih dari itu memperkenalkan seni dan budaya, kuliner dan keunggulankeunggulan lokal dari daerah masing-masing, serta sekaligus sebagai bentuk upaya menaikkan pendapatan daerah menuju kemandirian daerah. Tidak terkecuali Kota Pekalongan.

Sayangnya perkembangan ekonomi yang ada serta berbagai sumber daya yang melekat pada perkotaan ini tidak mampu mendongkrak kunjungan wisatawan pada obyekobyek wisata di Kota Pekalongan, terutama obyek wisata Pantai Pasir Kencana. Bahkan menurut data yang dapat dikutip dari BPS Kota Pekalongan dari tahun 2011 s.d. tahun 2015 ada kecenderungan yang menurun di kedua tempat tersebut. Berikut adalah data kunjungan wisatawan pada obyek wisata Pasir Kencana.

Tabel 1. Banyaknya Pengunjung dan Pendapatan Obyek Wisata Pasir Kencana Kota Pekalongan Tahun 2011 s.d. 2015

\begin{tabular}{c|c|c|c} 
Tahun & Wisman & Wisnus & Pendapatan (Rp) \\
\hline $\mathbf{2 0 1 5}$ & $\mathbf{0}$ & $\mathbf{1 6 7 . 9 2 3}$ & $\mathbf{7 4 5 . 4 9 3 . 7 5 0}$ \\
\hline 2014 & 0 & 169.584 & 594.273 .000 \\
\hline 2013 & 0 & 171.962 & 601.766 .000 \\
\hline 2012 & 0 & 171.962 & 601.766 .000 \\
\hline 2011 & 0 & 163.015 & 387.278 .800 \\
\multicolumn{2}{l}{ Sumber: BPS Kota Pekalongan }
\end{tabular}

Di tempat Obyek Wisata Pasir Kencana pada tahun 2015 jumlah pengunjung mayoritas wisatawan nusantara dengan jumlah pengunjung sebanyak 167.923. dibandingkan dengan tahun 2014 mengalami penurunan sebanyak 1661 wisatawan.

Fenomena di atas sungguh ironis mengingat perkembangan sumber daya yang melekat pada perkotaan yang semakin berkembang yang mestinya mampu mendukung perkembanngan jumlah wisatawan pada berbagai obyek wisata di Kota Pekalongan. Fenomena di atas menimbulkan pertanyaan yang membutuhkan jawaban yaitu, "faktorfaktor apakah yang menyebabkan penurunan jumlah wisatawan di Pantai Kota Pekalongan, terutama di Pantai Pasir Kencana?" oleh karena itu penting dilakukan kajian untuk menjawab pertanyaan yang dimaksud.

Dari latar belakang di atas, maka dapat ditentukan tujuan penelitian yang hendak dicapai sebagai berikut: 1) Mengetahui dan menganalisis kondisi aktual (fisik dan nonfisik) aspek pengembangan wisata di objek Wisata Pantai Kota Pekalongan. 2) Menganalisis kebijakan pengembangan objek Wisata Pantai di Kota Pekalongan sebagai strategi perencanaan pengembangan wisata Pantai Kota Pekalongan. 3) Menentukan strategi perencanaan pengembangan pariwisata berkelanjutan (Sustainable Tourism) dari objek Wisata Pantai di Kota Pekalongan dalam rangka pengembangan Wisata Pantai.

\section{KAJIAN PUSTAKA}

Istilah pariwisata berasal dari bahasa Sansekerta, yang terdiri dari "Pari" dan "Wisata". Pari yang berarti berulang-ulang, sedangkan Wisata adalah perjalanan atau bepergian. Pariwisata dapat diartikan perjalanan yang dilakukan secara berulang-ulang dengan mengunjungi satu tempat ke tempat lain. Setiap orang yang bepergian dari tempat tinggalnya untuk berkunjung ke tempat lain dengan menikmati perjalanan dan kunjungan 
itu disebut Traveller, sedangkan orang yang bepergian melintasi suatu negara dengan tidak singgah walaupun perjalanan itu sendiri melebihi jangka waktu 24 jam disebut Tourist (Warang, 2015). Sehingga pariwisata adalah perjalanan yang dilakukan berkali-kali untuk berputar-putar, dari suatu tempat ke tempat yang lain (Suwena, dkk, 2010).

Pariwisata adalah salah satu industri dari gaya baru, yang mampu meyediakan pertumbuhan ekonomi yang cepat dalam hal kesempatan kerja, pendapatan, taraf hidup dan dalam mengaktifkan sektor produksi lain di dalam negara penerima wisatawan. (Wahab, 2003). Berdasarkan hal tersebut, pariwisata dapat disimpulkan sebagai kegiatan sementara yang dilakukan oleh seseorang atau kelompok yang pergi dari satu tempat ke tempat lain di luar tempat tinggalnya dengan tujuan mengelilingi suatu daerah tertentu untuk tujuan tertentu misalnya kesenangan, rekreasi atau pengembangan diri yang didukung oleh sarana dan prasarana yang memungkinkan untuk terjadinya kegiatan tersebut.

Suwantoro (2004) menjelaskan bahwa pariwisata adalah suatu proses kepergian sementara seseorang atau lebih menuju tempat lain keluar tempat tinggalnya. Dorongan kepergiannya adalah karena berbagai kepentingan, baik karena kepentingan ekonomi, sosial, kebudayaan, politik, agama, kesehatan maupun kepentingan lain seperti karena sekedar ingin tahu, menambah pengalaman ataupun untuk belajar. Berdasarkan pendapat beberapa ahli di atas dapat disimpulkan bahwa pariwisata adalah suatu perjalanan dari suatu tempat ke tempat yang lain yang dilakukan oleh individu maupun kelompok yang bersifat sementara atau tidak untuk tinggal di tempat yang dikunjungi.

Menurut Yoeti (2008) pariwisata harus memenuhi empat kriteria di bawah ini, yaitu: 1) perjalanan dilakukan dari suatu tempat ke tempat lain, perjalanan dilakukan di luar tempat kediaman di mana orang itu biasanya tinggal; 2) tujuan perjalanan dilakukan semata-mata untuk bersenang-senang, tanpa mencari nafkah di negara, kota atau DTW yang dikunjungi. 3) uang yang dibelanjakan wisatawan tersebut dibawa dari negara asalnya, di mana dia bisa tinggal atau berdiam, dan bukan diperoleh karena hasil usaha selama dalam perjalanan wisata yang dilakukan; dan 4) perjalanan dilakukan minimal 24 jam atau lebih.

\section{METODE PENELITIAN}

Penelitian ini bersifat deskriptif, dilakukan untuk mendapatkan gambaran atau deskripsi tentang penilaian aspek-aspek pengembangan wisata bahari yang dilakukan melalui perhitungan statistik, kemudian dilakukan analisis pengembangan objek wisata yang dilakukan menggunakan teknik analisis SWOT, yaitu analisis untuk menemukan kekuatan, kelemahan, peluang dan ancaman terhadap produk, pasar, kebijakan dan program pemasaran. Metode yang digunakan dalam peneltian ini adalah metode survei, dimana informasi diperoleh dari responden yang dikumpulkan secara empiric untuk memperoleh pendapat dari sebagian populasi terhadap obyek penelitian. Berdasarkan jenis data dan analisisnya, desain penelitian ini merupakan sebagai gabungan data penelitian kuantitatif serta data kualitatif.

Populasi dalam penelitian ini adalah Pengunjung Obyek Wisata Pantai Pasir Kencana, Hal itu diharapkan agar hasil yang didapatkan dalam penelitian ini bisa lebih efektif serta sesuai dengan apa yang peneliti inginkan. Sampel dalam penelitian ini adalah Pengunjung Obyek Wisata Pantai Pasir Kencana, di Kota Pekalongan. 


\section{HASIL DAN PEMBAHASAN}

Kota Pekalongan terletak antara 109037'55" Bujur Timur dan 6050'42” - 6055'44” Lintang Selatan, berada pada jalur jalan regional utara Pulau Jawa antara Jakarta Semarang - Surabaya, yang dibatasi oleh Laut Jawa di Sebelah Utara, Kabupaten Pekalongan di Sebelah Barat, Kabupaten Pekalongan dan Kabupaten Batang di Sebelah Selatan dan Kabupaten Batang di Sebelah Timur. Luas Wilayah Kota Pekalongan adalah $44,86 \mathrm{~km} 2$ atau $4.486 \mathrm{Ha}$. Jarak terjauh dari utara ke selatan $9 \mathrm{~km}$ dan dari barat ke timur 7 $\mathrm{km}$. Ketinggian lahan antara 0 meter di atas permukaan laut pada bagian utara dan 6 meter di atas permukaan laut pada bagian selatan, dengan kemiringan antara $0-5 \%$.

Pemerintah Kota Pekalongan terus berbenah menggali potensi-potensi yang ada. Upaya pengembangan kepariwisataan di Kota Pekalongan tidak terlepas dari upaya pembangunan bidang-bidang yang lain yang telah dilakukan selama ini. Upaya-upaya tersebut tidak hanya berkaitan dengan pemeliharaan dan pelestarian budaya sebagai salah satu obyek kepariwisataan yang ada sebelumnya. Namun juga telah bergerak pada upaya pencarian berbagai potensi wisata yang dapat dikembangkan di masa-masa yang akan datang.

Obyek Wisata Pantai Pasir Kencana merupakan obyek wisata utama yang dimiliki Pemerintah Kota Pekalongan. Terletak berbatasan dengan Tempat Pelelangan Ikan atau Pelabuhan Perikanan Nusantara di Pantai Utara Jawa, dengan jarak tempuh 4,5 km dari kota/stasiun kereta api, luas lahan pantai ini adalah 1,5 Ha. Obyek wisata yang dikelola oleh Dinas Pariwisata, Kebudayaan, Kepemudaan dan Olahraga Kota Pekalongan ini dibuka untuk umum dari jam 06.00 WIB - 21.00 WIB.

Berikut adalah gambar yang menjelaskan penilai kinerja Pelayanan di Obyek Wisata Pantai Pasir Kencana Pekalongan. 


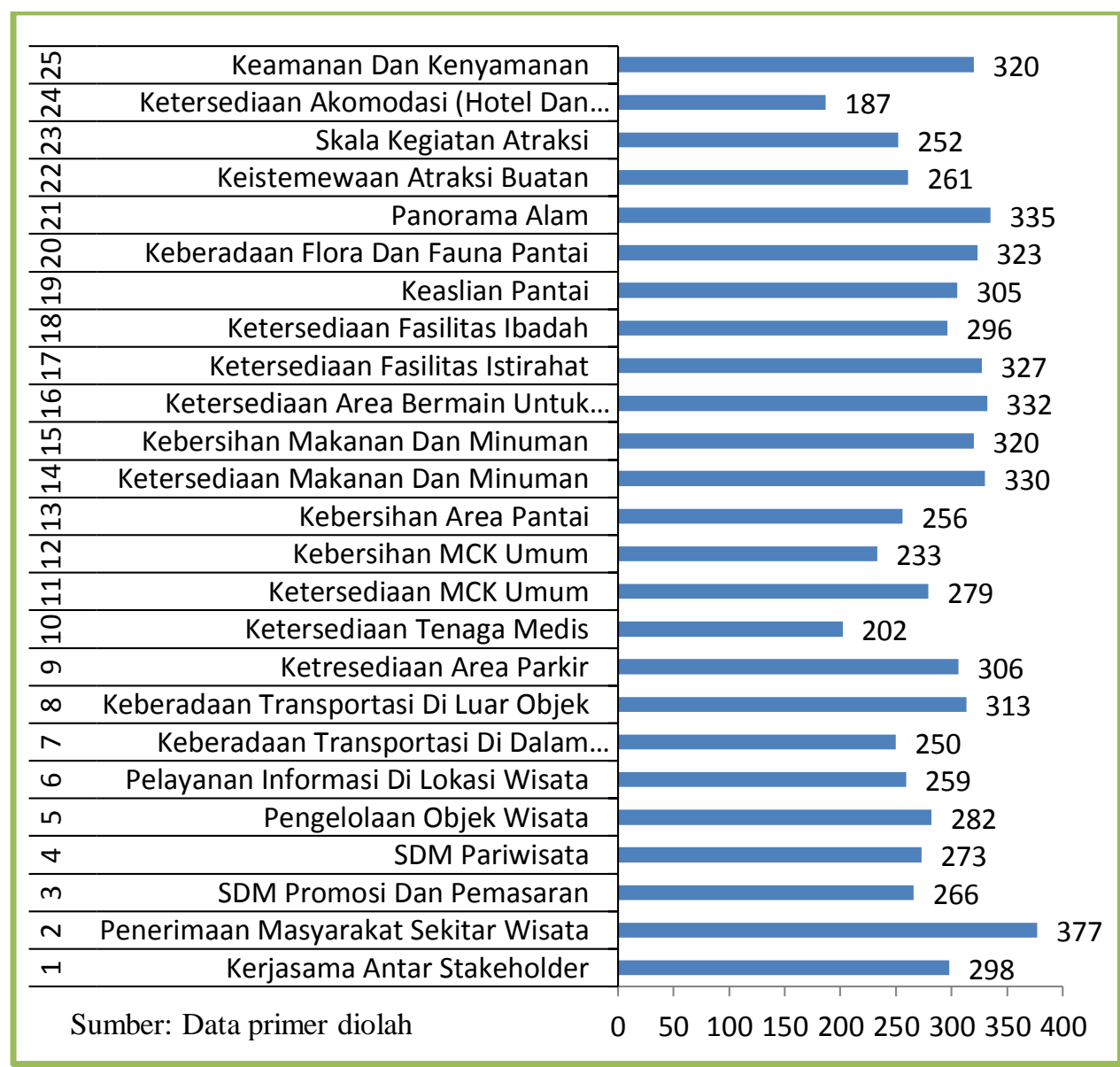

Gambar 1. Grafik Penilai Kinerja Pelayanan Wisata Pasir Kencana Pekalongan

Berdasarkan penilaian pengunjung atas 25 point pertanyaan yang diajukan, dapat diketahui bahwa nilai kinerja pelayanan wisata Pantai Pasir Kencana Pekalongan rata-rata sebesar 2,87 atau dapat dikatakan bahwa kinerja pelayanan wisata pantai pasir kencana dalam katagori tidak baik. Nilai kinerja tertinggi adalah pada aspek penerimaan masyarakat sekitar sebesar 3,77 atau dalam katagori kinerja baik dan nilai terendah adalah pada aspek ketersediaan akomodasi di sekitar lokasi wisata sebesar 1,87 atau dalam kategori kinerja sangat tidak baik.

Berikut adalah Tabel yang menjelaskan penilai kinerja Pelayanan di Obyek Wisata Pantai Pasir Kencana Pekalongan:

Tabel 2. Penilaian Kinerja Pelayanan Obyek Wisata Pantai Pasir Kencana

\begin{tabular}{l|c|c|c}
\multicolumn{1}{c|}{ Indikator } & Jumlah & Rata-rata & Kinerja \\
\hline Kerjasama Antar Stakeholder & 298 & 2,98 & Tidak Baik \\
\hline Penerimaan Masyarakat Sekitar Wisata & 377 & 3,77 & Cukup Baik \\
\hline SDM Promosi Dan Pemasaran & 266 & 2,66 & Tidak Baik \\
\hline SDM Pariwisata & 273 & 2,73 & Tidak Baik \\
\hline Pengelolaan Objek Wisata & 282 & 2,82 & Tidak Baik \\
\hline Pelayanan Informasi Di Lokasi Wisata & 259 & 2,59 & Tidak Baik \\
\hline Keberadaan Transportasi Di Dalam Objek & 250 & 2,50 & Tidak Baik \\
\hline Keberadaan Transportasi Di Luar Objek & 313 & 3,13 & Cukup Baik \\
\hline Ketresediaan Area Parkir & 306 & 3,06 & Cukup Baik \\
\hline Ketersediaan Tenaga Medis & 202 & 2,02 & Tidak Baik \\
\hline Ketersediaan MCK Umum & 279 & 2,79 & Tidak Baik
\end{tabular}




\begin{tabular}{l|c|c|c}
\multicolumn{1}{c|}{ Indikator } & Jumlah & Rata-rata & Kinerja \\
\hline Kebersihan MCK Umum & 233 & 2,33 & Tidak Baik \\
\hline Kebersihan Area Pantai & & 2,56 & Tidak Baik \\
\hline Ketersediaan Makanan Dan Minuman & 330 & 3,30 & Cukup Baik \\
\hline Kebersihan Makanan Dan Minuman & 320 & 3,20 & Cukup Baik \\
\hline Ketersediaan Area Bermain Untuk Anak-Anak & 332 & 3,32 & Cukup Baik \\
\hline Ketersediaan Fasilitas Istirahat & 327 & 3,27 & Cukup Baik \\
\hline Ketersediaan Fasilitas Ibadah & 296 & 2,96 & Tidak Baik \\
\hline Keaslian Pantai & 305 & 3,05 & Cukup Baik \\
\hline Keberadaan Flora Dan Fauna Pantai & 323 & 3,23 & Cukup Baik \\
\hline Panorama Alam & 335 & 3,35 & Cukup Baik \\
\hline Keistemewaan Atraksi Buatan & 261 & 2,61 & Tidak Baik \\
\hline Skala Kegiatan Atraksi & 252 & 2,52 & Tidak Baik \\
\hline Ketersediaan Akomodasi (Hotel Dan & 187 & 1,87 & Sangat Tidak \\
Penginapan) & 320 & 3,20 & Cukup Baik \\
\hline Keamanan Dan Kenyamanan & $\mathbf{2 8 7}$ & $\mathbf{2 , 8 7}$ & Tidak baik
\end{tabular}

Sumber: Data primer diolah

Dari tabel di atas menunjukkan bahwa mayoritas pengunjung menilai bahwa kinerja pelayanan wisata Pantai Pasir Kencana tidak ada yang benar-benar menunjukkan katagori baik, yang ada hanya dalam katagori cukup baik atau mendekati baik. Namun demikian hal yang menarik dan masih bisa dijadikan modal dasar pengembangan wisata pantai adalah aspek atraksi alam yaitu aspek yang berkaitan dengan kondisi alam di pantai pasir kencana seperti keaslian pantai, keberadaan flora fauna, dan panorama alam dimana dalam persepsi pengunjung aspek ini dinilai cukup baik.

Data-data penilai kinerja tersebut selanjunya dipetakan ke dalam kekuatan dan kelemahan untuk kepentingan strategi perencanaan pengembangan destinasi wisata pantai pasir kencana. Dari pemetaan tersebut diperoleh 11 aspek yang di masukkan dalam faktor kekuatan yaitu: (2) Penerimaan Masyarakat Sekitar Wisata, (8) Keberadaan Transportasi di Luar Obyek wisata, (9) Ketersediaan Area Parkir, (14) Ketersedian makanan dan minuman, (15) kebersihan Makanan dan Minuman, (16) Ketersediaan Area Bermain Untuk AnakAnak, (17) ketersediaan area istirahat, (19) Keaslian Pantai, (20) Keberadaan Flora Dan Fauna Pantai (21) Panorama Alam, dan (25) Keamanan Dan Kenyamanan

Sementara itu aspek yang dimasukkan kedalam faktor kelemahan adalah: (1) kerjasama, (3) SDM promosi dan pemasaran, (4) SDM Pariwisata, (5) pengelolaan obyek wisata, (6) Pelayanan Informasi Di Lokasi Wisata (7) Pelayanan Informasi Di Lokasi Wisataoyek wisata, (10) Ketersediaan Tenaga Medis (11) Ketersediaan MCK Umum, (12) Kebersihan MCK Umum (13) Kebersihan Area Pantai, (18) Ketersediaan Fasilitas Ibadah (22) Keistemewaan Atraksi Buatan, (23) Skala Kegiatan Atraksi, dan (24) Ketersediaan Akomodasi (Hotel Dan Penginapan).

Dari Faktor internal dan Faktor Eksternal yang ada selanjutnya dimasukkan kedalam Matrik SWOT sebagai bahan penentuan strategi perencanaan pengembangan destinasi wisata: 
Tabel 3. Matrik SWOT Destinasi Wisata Pantai Pasir Kencana Kota Pekalongan

\begin{tabular}{|c|c|c|}
\hline IFAS & $\begin{array}{l}\text { STRENGTHS (S) } \\
\text { Transportasi di luar obyek, keter- } \\
\text { sediaan dan kebersihan makanan } \\
\text { dan minuman, arena bermain, } \\
\text { ruang parkir, istirahat, jenis dan } \\
\text { skala atraksi buatan }\end{array}$ & $\begin{array}{l}\text { WEAKNESSES }(\mathrm{W}) \\
\text { Kerjasama, promosi, pengelolaan, } \\
\text { informasi, transportasi dalam } \\
\text { obyek, tempat ibadah, akomodasi. }\end{array}$ \\
\hline $\begin{array}{l}\text { OPPORTUNITIES }(\mathrm{O}) \\
\text { Penerimaan masyarakat, per- } \\
\text { kembangan pusat perbelan- } \\
\text { jaan, perbankan, hotel, resto- } \\
\text { ran/kuliner, dukungan peme- } \\
\text { rintah, dan pertumbuhan eko- } \\
\text { nomi, serta perkem-bangan } \\
\text { medsos. }\end{array}$ & $\begin{array}{l}\text { STRATEGIS - O } \\
\text { 1.Mempertahankan posisi seba-gai } \\
\text { tempat wisata yang memiliki } \\
\text { keistimewaan-keistimewaan, ber- } \\
\text { fasilitas lengkap dan mudah di- } \\
\text { jangkau serta mengikutsertakan } \\
\text { masyarakat dalam pengem- } \\
\text { bangannya. } \\
\text { 2. Mempertahankan posisi sebagai } \\
\text { tempat wisata yang memiliki objek } \\
\text { wisata pendukung dengan harga } \\
\text { terjangkau serta menerapkan } \\
\text { diversifikasi harga. } \\
\text { 3.Mempertahankan posisi seba-gai } \\
\text { tempat wisata dengan menerapkan } \\
\text { strategi promosi yang meman- } \\
\text { faatkan perkembangan teknologi } \\
\text { serta didukung oleh manajemen } \\
\text { pengelolaan yang baik. } \\
\text { 4.Menjalin kerjasama dengan pihak } \\
\text { luar dalam rangka meningkatkan } \\
\text { kunjungan wisatawan dengan } \\
\text { memanfaatkan kondisi dan sumber } \\
\text { daya yang ada. }\end{array}$ & $\begin{array}{l}\text { STRATEGI } \mathrm{W}=\mathrm{O} \\
\text { 1.Mengembangkan strategi promosi } \\
\text { yang berorientasi nasional dengan } \\
\text { menggunakan teknologi informasi } \\
\text { dan bekerjasama dengan pihak lain } \\
\text { yang terkait dalam jaringan pema- } \\
\text { saran wisata. } \\
\text { 2.Bekerjasama dengan masyarakat } \\
\text { dan pemda dalam meng- } \\
\text { embangkan objek wisata yang } \\
\text { bertujuan untuk menyejahterakan } \\
\text { masyarakat di sekitar objek wisata. } \\
\text { 3.Bekerjasama dengan pemerintah } \\
\text { dan pihak-pihak terkait lainnya } \\
\text { dalam meningkatkan pelayanan } \\
\text { kepariwisataan daerah } \\
\text { 4.Mengembangkan jenis wisata pan- } \\
\text { tai/bahari dengan menerapkan stra- } \\
\text { tegi diversifikasi produk melalui } \\
\text { penelitian dan pengembangan } \\
\text { pasar }\end{array}$ \\
\hline $\begin{array}{l}\text { TREATHS }(\mathrm{T}) \\
\text { Keterbatasan dana peme- } \\
\text { rintah, tingkat kepe-dulian } \\
\text { dunia usaha perilaku } \\
\text { masyarakat yang buruk, dan } \\
\text { Operasional jalan tol, }\end{array}$ & $\begin{array}{l}\text { STRATEGI S-T } \\
\text { 1.Mempromosikan tempat wisata } \\
\text { yang menarik dan aman untuk di- } \\
\text { kunjungi. } \\
\text { 2. Mengoptimalkan dan mening- } \\
\text { katkan kualitas produk wisata serta } \\
\text { memberikan harga yang terjangkau } \\
\text { bagi semua golongan ekonomi. } \\
\text { 3. Memberikan penyuluhan dan meli- } \\
\text { batkan masyarakat sekitar dalam } \\
\text { program-program wisata yang } \\
\text { menyangkut pemeliharaan dan } \\
\text { pengembangan objek wisata. } \\
\text { 4. Bekerjasama dengan pemerintah } \\
\text { untuk menciptakan iklim investasi } \\
\text { yang kondusif di sektor pariwisata. }\end{array}$ & $\begin{array}{l}\text { STRATEGI W - T } \\
\text { 1.Melakukan kerjasama dengan } \\
\text { pihak-pihak terkait serta masya- } \\
\text { rakat dalam menciptakan kein- } \\
\text { dahan, ketertiban, dan keamanan } \\
\text { di kawasan objek wisata. } \\
\text { 2.Peningkatan kualitas wisata } \\
\text { dengan memberikan kemudahan } \\
\text { bagi pihak lain untuk mengadakan } \\
\text { penelitian dan mendirikan suatu } \\
\text { usaha jasa wisata. } \\
\text { 3.Mengembangkan jaringan pema- } \\
\text { saran wisata melalui pameran dan } \\
\text { event-event kepariwisataan. } \\
\text { 4.Melakukan pendidikan dan pela- } \\
\text { tihan secara rutin dengan tujuan } \\
\text { untuk meningkatkan keterampilan } \\
\text { dan pengetahuan aparatur di } \\
\text { bidang pariwisata. }\end{array}$ \\
\hline
\end{tabular}

Tabel 4. Strategi Kebijakan Pengembangan Wisata Pasir Kencana Pekalongan

\begin{tabular}{|c|c|c|}
\hline \multirow{2}{*}{$\begin{array}{l}\text { Strategi } \\
\text { Pengembangan }\end{array}$} & Kebijakan Jangka Pendek & Kebijakan Jangka Panjang \\
\hline & Kegiatan & Kegiatan \\
\hline Kebijakan & $\begin{array}{l}\text { 1. Membuat buku pedoman kunjungan wisata } \\
\text { di Kota Pekalongan } \\
\text { 2. Pembinaan SDM Pariwisata: pengaturan, } \\
\text { pengendalian, pengawasan, dan penerapan } \\
\text { sanksi. } \\
\text { 3. Pembinaan bagi para pedagang/kuliner: } \\
\text { pengaturan, pengendalian, pengawasan dan } \\
\text { penerapan sanksi: }\end{array}$ & $\begin{array}{l}\text { 1. Pengembangan kualitas SDM pariwisata melalui } \\
\text { berbagai pelatihan } \\
\text { 2. Meningkatkan partisipasi Masyarakat sekitar lokasi } \\
\text { wisata Pasir Kencana untuk meningkatkan kualitas } \\
\text { pelayanan wisata. } \\
\text { 3. Mumbuka Kerjasama yang lebih luas dengan pihak } \\
\text { swasta agar mau berinvestasi di kawasan wisata } \\
\text { Pantai Kencana } \\
\text { 4. Membuat dan mensosialisasikan Perda tentang } \\
\text { peluang investasi di kawasan wisata pasir kencana }\end{array}$ \\
\hline
\end{tabular}




\begin{tabular}{|c|c|c|}
\hline $\begin{array}{l}\text { Fasilitas dan } \\
\text { Aktivitas }\end{array}$ & $\begin{array}{l}\text { 1. Peningkatan fasilitas fasilitas pada obyek } \\
\text { wisata secara bertahap hingga memenuhi } \\
\text { standar mutu. } \\
\text { 2. Peningkatan kerjasama dengan stakeholders } \\
\text { 3. Penyediaan Sarana Peribadatan yang baik }\end{array}$ & $\begin{array}{l}\text { 1. Menyatukan Objek Wisata Pasir Kencana dengan } \\
\text { Obyek Wisata Bahari PPNP } \\
\text { 2. Peningkatan aktivitas wisata buatan, baik ragam } \\
\text { aktivitas buatan hingga skala kegiatan. (sarana } \\
\text { Outbond, sarana edukasi dan bermain) } \\
\text { 3. Mengembangkan Wisata religius memalui } \\
\text { pembuatan Masjid Agung sebagai sarana islamic } \\
\text { centre di kawasan Pasir Kencana. }\end{array}$ \\
\hline Bauran Pemasaran & $\begin{array}{l}\text { 1. Produk: menciptakan manfaat, kemasan, } \\
\text { produk inti, produk penunjang, produk } \\
\text { pendukung, produk pelengkap wisata Pasir } \\
\text { Kencana } \\
\text { 2. Penetapan Kebijakan Harga (Price): } \\
\text { Penciptaan Harga, diskon, cara pembayaran } \\
\text { 3. Place (Penyaluran/Distribusi): pemben- } \\
\text { tukan Agen, outlet, akses wisatawan } \\
\text { 4. Promotion (Promosi): Penjualan langsung, } \\
\text { sales promotion, iklan, } \\
\text { 5. Proccess (Proses): Proses yang dilalui } \\
\text { wisatawan untuk menikmati rekreasi sejak } \\
\text { mulai berangkat, dalam perjalanan, } \\
\text { kedatangan, dalam kawasan rekreasi, } \\
\text { kepulangan } \\
\text { 6. Penampilan Fisik (Physical Evidence): Re- } \\
\text { vitalisasi Visual Pasir Kencana, keindahan, } \\
\text { kebersihan, Pengurangan bau, dan } \\
\text { kebisingan } \\
\text { 7. Pengelola Wisata (People): Kompetensi, } \\
\text { keramahtamahan, pelayanan, komunikasi, } \\
\text { perilaku SDM wisata. }\end{array}$ & $\begin{array}{l}\text { 1. Produk: pengembangan manfaat, kemasan, produk } \\
\text { inti, produk penunjang, produk pendukung, produk } \\
\text { pelengkap wisata Pasir Kencana } \\
\text { Penetapan Kebijakan Harga (Price): Pengem- } \\
\text { bangan Harga, diskon, cara pembayaran melalui } \\
\text { paket wisata secara holistik } \\
\text { 3. Place (Penyaluran/ Distribusi): Pengembangan } \\
\text { Agen, outlet, akses wisatawan } \\
\text { 4. Promotion (Promosi): pengembangan iklan } \\
\text { melalui media TV nasional, pameran, travel mart, } \\
\text { travel exchange, pembuatan pintu gerbang di jalan } \\
\text { pantura, pembuatan baliho. } \\
\text { Proccess (Proses): pengembangan proses yang } \\
\text { dilalui wisatawan untuk menikmati rekreasi sejak } \\
\text { mulai berangkat, dalam perjalanan, kedatangan, } \\
\text { dalam kawasan rekreasi, kepulangan } \\
\text { Penampilan Fisik (Physical Evidence): revi- } \\
\text { talisasi Visual Pasir Kencana, keindahan, } \\
\text { kebersihan, Pengurangan bau, dan kebisingan } \\
\text { Pengelola Wisata (People): pengembangan } \\
\text { Kompetensi, keramahtamahan, pelayanan, komu- } \\
\text { nikasi, perilaku SDM Wisata }\end{array}$ \\
\hline
\end{tabular}

\section{SIMPULAN DAN SARAN}

Berdasarkan tujuan dan hasil penelitian yang dilakukan maka dapat ditarik kesimpulan sebagai berikut: Secara keseluruhan dapat disimpulkan bahwa Kondisi prasarana dan sarana pariwisata di lokasi pariwisata Pantai Pasir Kencana, masih sangat kurang memadai seperti jaringan listrik dan lampu penerangan, jaringan air bersih, fasilitas kesehatan, fasilitas sanitasi dan kebersihan, fasilitas lahan parkir, fasilitas ibadah, fasilitas akomodasi, penunjuk arah, yang masih kurang memadai, dan jaringan telekomunikasi, fasilitas keamanan, fasilitas keuangan, fasilitas bisnis, fasilitas rekreasi, fasilitas informasi dan pelayanan pariwisata, polisi pariwisata dan satuan wisata, toko cendera mata, papan informasi pariwisata/rambu lalu lintas wisata, dan bentuk bentang alam yang belum tersedia dilokasi pariwisata Pantai Pasir Kencana.

Berdasarkan kesimpulan yang telah diuraikan diatas, maka saran yang dapat diberikan sebagai berikut : 1) Pemerintah Kota Pekalongan lebih memberikan perhatian terhadap kebutuhan prasarana dan sarana pariwisata yang ada di kawasan Pantai Pasir Kencana. 2) Pemerintah Kota Pekalongan perlu membuat UU mengenai pariwisata dan menerapkan kebijakankebijakan yang terkait dengan wisata. 3) Pemerintah Kota Pekalongan memberikan sosialisasi kepada masyarakat maupun wisatawan tentang wisata 4) Pemerintah Kota Pekalongan Perlu adanya promosi dan pemasaran yang lebih baik dan meluas. Agar masyarakat umum mengetahui tentang keberadaan Wisata Pantai Pasir Kencana. 5) Pemerintah Kota Pekalongan perlu adanya pengikut sertaan acara budaya di lokasi obyek yang mana akan mampu menambah daya tarik Objek Wisata Pantai Pasir Kencana. 6) Pemerintah Kota Pekalongan dalam mengembangkan Obyek Wisata Pantai haruslah melibatkan berbagai pihak yang saling terkait satu dengan yang lain dan tidak dapat dipisahkan, yaitu masyarakat sekitar, pihak pemerintah serta pihak swasta. 


\section{DAFTAR PUSTAKA}

Suwantoro, G. 2004. Dasar-Dasar Pariwisata. Yogyakarta: Andi.

Suwena, I.K \& Widyatmaja, G.N. 2010. Pengetahuan Dasar Ilmu Pariwisata. Denpasar-Bali: Udayana University.

Wahab, S. 2003. Manajemen Kepariwisataan (alih bahasa: Frans Gromang). Jakarta: Pradnya Paramita

Warang. T. R. 2015. Kajiang Pengembangan Wisata Pantai di Sulabesi Kabupaten Kepulauan Sula Propinsi Maluku Utara. Skripsi Program Studi Perencanaan Wilayah Dan Kota Universitas Sam Ratulangi Manado.

Yoeti, O, A. 2008 Perencanaaan dan Pengembangan Pariwisata. Jakarta, Pradaya Pratama 